\title{
Campanian and Maastrichtian plagioptychid rudists (Hippuritida, Bivalvia) of the Chiapas Central Depression, southern Mexico
}

\author{
Jose Maria Pons, ${ }^{1}$ Enric Vicens, ${ }^{1}$ and Pedro García-Barrera ${ }^{2}$ \\ ${ }^{1}$ Departament de Geologia, Universitat Autònoma de Barcelona, E-08193 Bellaterra, Spain 〈josepmaria.pons@uab.cat〉, 〈enric.vicens@uab.cat〉 \\ ${ }^{2}$ Facultad de Ciencias, Universidad Nacional Autónoma de México, Mexico 〈pedrogarciab@ciencias.unam.mx〉
}

\begin{abstract}
Plagioptychids are a conspicuous, although minor, component in uppermost Cretaceous rudist-bearing outcrops of the Caribbean Province, where other rudist families are more abundant and diverse. In the Chiapas Central Depression, the plagioptychid rudist fauna includes the following taxa: Plagioptychus antillarum (Douvillé) and Mitrocaprina sp. from the middle Campanian Suchiapa Formation, Plagioptychus muellerriedi Alencáster from the early Maastrichtian Ocozocoautla Formation, and Plagioptychus fragilis Chubb and Mitrocaprina tschoppi (Palmer) from the late Maastrichtian Angostura Formation. These five species are described in detail and some probable synonymies are discussed. Analysis of the literature on American plagioptychids reveals that the characters of too many taxa are still insufficiently known to attempt any thorough phylogenetic analysis. Other lines of evidence also seem to indicate that American Plagioptychidae diversity is probably higher than recognized today, which might result in a more significant difference to Plagioptychidae of the Mediterranean Tethys.
\end{abstract}

\section{Introduction}

In the American Tethys, families Antillocaprinidae, Hippuritidae (mainly multiple-fold), and Radiolitidae represent the maximal rudist abundance and diversity in the uppermost Cretaceous rudist-bearing outcrops of the Caribbean Province, while family Plagioptychidae is a minor, although conspicuous, component (Table 1). Among the latter, the genus Coralliochama is exclusive of the American Tethys, but its presence in the Caribbean region is doubted by some. Mitrocaprina and Plagioptychus occur on both sides of the Atlantic, although with different species at each side; the Mediterranean species identified in America have been shown to be erroneous. Several among the formerly established Caribbean plagioptychid species were based on only one or very few specimens and their morphological characters are not satisfactorily known. Thus, their identification based on new findings becomes problematic. Moreover, the precise biostratigraphy of some species remains uncertain because many Upper Cretaceous Caribbean outcrops correspond to short stratigraphic sections without direct field correlation among them.

Mexico presents a particularly long, largely continuous and extensive sedimentary record of the Upper Cretaceous in rudistbearing platforms and deeper facies. Chiapas, in southern Mexico, was clearly related to the tectonic evolution of the Caribbean, and its sedimentary and paleontological record is much more continuous, or at least easier to interpret than that of the islands. The Upper Cretaceous rudist fauna of Chiapas is mainly known from Alencáster (1971) and older papers by Müllerried (1931a, 1931b, 1933, 1934, 1936). More recent papers (Alencáster and Michaud, 1991; Alencáster and Pons, 1992; García-Barrera et al., 1998; Mitchell, 2013) added some complementary taxonomic data to the knowledge of this fauna. Pons et al. (2016a) provided the inventory of rudist occurrences in the Upper Cretaceous of the Chiapas Central Depression, related their location to a lithostratigraphic framework and paleogeographic reconstruction, identified the successive rudist assemblages, and discussed their age based on the co-occurrence of other fossils. Nevertheless, current and detailed systematic description of all these rudist species is yet to be done.

The main aim of this paper is the identification and description of the plagioptychid rudist species from the Campanian and Maastrichtian of this area, based mainly on the specimens collected by the authors, but also on the revision of fossil material from different museum collections, and taking into account the recent taxonomic and biostratigraphic advances on the knowledge of the Caribbean Late Cretaceous rudist faunas.

\section{Geologic Setting}

Localities and stratigraphy.-Specimens for this study were collected at five localities of the Chiapas Central Depression (Fig. 1) corresponding to three different lithostratigraphic units and to three of the rudist assemblages distinguished in Pons et al. (2016a). Coincidence with Müllerried's localities is also indicated when appropriated; although never published by Müllerried, numbers and names of his fossil localities were registered in the collection, and subsequently used and indicated in a map by Alencáster (1971).

P-1316, road to Paraíso del Grijalva (92³8'15.5"W, $16^{\circ} 15^{\prime} 15.94$ "N) in the uppermost part of the Suchiapa Formation, corresponds to Müllerried's locality 30 Vega del Paso, and 
Table 1. American plagioptychid rudist taxa.

\begin{tabular}{l}
\hline American Plagioptychidae \\
\hline Coralliochama White \\
C. flourei Damestoy \\
C. gboehmi Böse \\
C. orcutti White \\
Mitrocaprina Boehm \\
M. costaricaensis Pons et al. \\
M. multicanaliculata Chubb \\
M. palmeri MacGillavry \\
M. tschoppi (Palmer) \\
Plagioptychus Matheron \\
P. antillarum (Douvillé) \\
P. fragilis Chubb \\
P. jamaicensis (Whitfield) \\
P. minor Chubb \\
P. muellerriedi Alencáster \\
P. trechmanni Chubb \\
P. zansi Chubb \\
\hline
\end{tabular}

to the lower rudist assemblage, middle Campanian. Co-occurring rudists are: Alencasteria macrotubularis Mitchell, Stellacaprina? macgillavryi (Alencáster), Barrettia monilifera Woodward, Whitfieldiella gigas (Chubb), Parastroma trechmanni Chubb, Alencasterites mooretownensis (Trechmann), Bournonia bailei Chubb, and Thyrastylon? nicholasi (Whitfield).

P-0743, Campo de Tiro (93⒉'52.49"W, 16 $\left.466^{\prime} 55.41^{\prime \prime N}\right)$ and P-1358, Los Chamaquitos $\left(93^{\circ} 22^{\prime} 44.9^{\prime \prime} \mathrm{W}, 1^{\circ} 46^{\prime}\right.$ $35.58 " \mathrm{~N}$ ), both along the Cuesta NW of Ocozocoautla, in the upper part of the Ocozocoautla Formation, correspond to Müllerried's locality 6 Ocozocoautla, and to the middle rudist assemblage, early Maastrichtian. Co-occurring rudists are: Praebarrettia sparcilirata (Whitfield), Biradiolites cardenasensis Böse, Chiapasella radiolitiformis (Trechmann), Huasteca ojanchalensis (Myers), Thyrastylon? nicholasi (Whitfield), and Trechmannites rudissimus (Trechmann).

P-0748, Rancho la Peregrina $\left(93^{\circ} 22^{\prime} 11.27^{\prime \prime} \mathrm{W}\right.$, $\left.16^{\circ} 48^{\prime} 38.12^{\prime \prime N}\right)$ and P-1369, Old Quarry $\left(93^{\circ} 20^{\prime} 56.97^{\prime \prime} \mathrm{W}\right.$, $16^{\circ} 48^{\prime} 1.33^{\prime \prime N}$ ), at $189 \mathrm{~km}$ and $195.3 \mathrm{~km}$, respectively, road (Mex 145) from Ocozocoautla to Las Choapas, in the Angostura Formation, correspond to the upper assemblage, late Maastrichtian. Co-occurring rudists are: Antillocaprina pugniformis (Palmer), Caenosarcolites oddsensis (Stephenson), Caenosarcolites scholaris Mitchell, Eosarcolites radiatus Mitchell, Biradiolites cardenasensis Böse, Bournonia cancellata (Whitfield), and Thyrastylon adhaerens (Whitfield).

\section{Materials and Methods}

Methods.-Specimens collected and used for this study are maintained in the Paleontological Collections of the Universitat Autònoma de Barcelona (PUAB) and the Museo de Paleontología, Facultad de Ciencias, Universidad Nacional Autónoma de México (FCMP). Previous collections examined in this study include those from the Colección Nacional de Paleontología, Instituto de Geología, Universidad Nacional Autónoma de México (IGM), the Colección de la Unión Nacional de Geología de Cuba (now in Museo Nacional de Historia Natural [MNHNCu]), and the Collection de l'École nationale supériéure des Mines de Paris (now in Université Claude Bernard Lyon I [UCBL-EM]). Specimens were sectioned and polished, and acetate peels prepared, in the laboratories of the first two above-mentioned institutions.
Anatomical conventions. $-\mathrm{AM}=$ anterior myophore, $\mathrm{AS}=$ attachment surface of the right valve, AT $=$ anterior tooth, $\mathrm{CT}=$ central tooth, $\mathrm{ISL}=$ inner shell layer, $\mathrm{LG}=$ ligament groove, $\mathrm{LV}=$ left valve, $\mathrm{MC}=$ main body cavity, $\mathrm{OSL}=$ outer shell layer, $\mathrm{PAC}=$ posterior accessory cavity, $\mathrm{PM}=$ posterior myophore, $\mathrm{PT}=$ posterior tooth, $\mathrm{RV}=$ right valve. All transverse sections are figured in standard orientation, that is, in adapical view and with the dorsal side up. In cross-section drawings, the OSL is represented in black, RV's ISL in pale gray, and LV's ISL in dark gray. Lateral views of specimens with conjoined valves have been oriented with the RV's attachment area horizontal and down.

Repositories and institutional abbreviations. $-\mathrm{MNHNCu}=$ Museo Nacional de Historia Natural, Havana, Cuba; $\mathrm{NMNH}=$ Smithsonian, National Museum of Natural History, New York, USA; UCBL-EM=École nationale supériéure des Mines de Paris, Université Claude Bernard Lyon I, Villeurbanne, France; UWIGM = University of West Indies Geology Museum, Mona, Kingston, Jamaica.

\section{Systematic paleontology}

Family Plagioptychidae Douvillé, 1888 Genus Plagioptychus Matheron, 1842

Type species.-Plagioptychus paradoxus Matheron, 1842 [= Caprina aguilloni d'Orbigny, 1840, after Douvillé (1888)], from the Santonian? of Le Beausset, Bouches-du-Rhône, France.
Plagioptychus antillarum (Douvillé, 1927)
Figures 2.1-2.14, 3.1-3.5, 4.1

1927 Coralliochama antillarum Douvillé, p. 53, text-fig. 2. 1933 Plagioptychus Toucasi; Müllerried, p. 9, text-figs. 6-11. non 1936 Plagioptychus antillarum; Rutten, p. 140, text-fig. 4c, $\mathrm{d}, \mathrm{f}, \mathrm{j}$.

non 1937 Plagioptychus antillarum; MacGillavry, p. 156.

1971 Plagioptychus cf. P. jamaicensis; Alencáster, p. 21, pl. 1, figs. $1-4$, pl. 17, fig. 5. (pl. 1, fig. $1=$ same specimen as in Müllerried, 1933, text-fig. 7)

2016a Plagioptychus sp.; Pons et al., p. 217.

Types.-Holotype UCBL-EM-15901, figured in Douvillé (1927, text-fig. 2), from Arroyo Hondo, Camagüey Province, Cuba.

Diagnosis.-Medium to large shell with both valves differing in form and size. RV gyropleuriform, low conical, with highly eccentric apex, and attachment surface at the posteriordorsal margin; at the commissure, dorsal margin straight and the rest semielliptical, broader anteriorly and narrower posteriorly; commissural plane oblique to the growth axis. LV convex, wide umbo only slightly coiled anteriorly, projected dorsally, and covering parts of the right valve; pallial canals walls bifurcate twice, but three or more times and asymmetrically at the posterior side. Anterior myophore 

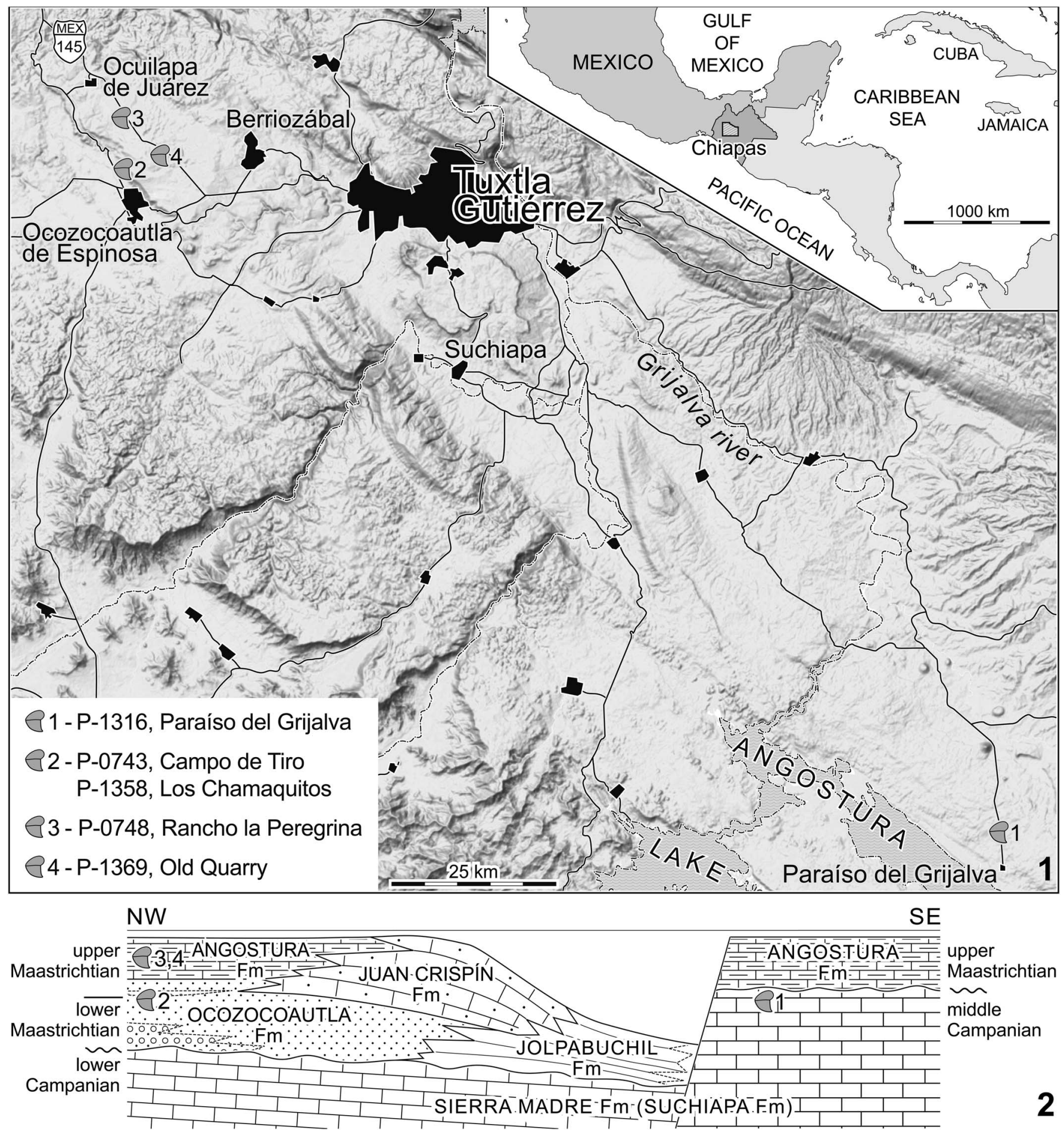

Figure 1. Map of fossil localities (shaded topographic relief from Google Maps): (1) Chiapas Central Depression; (2) depositional model showing stratigraphic position of samples. Modified from Pons et al. (2016a).

wide, teeth narrow and posteriorly aligned, LV's main cavity large and posterior accessory cavity small and narrow.

Occurrence.-Suchiapa Formation (upper part of Sierra Madre Formation in available geologic maps; discussion in Pons et al., 2016a), middle Campanian, of the Chiapas Central Depression,
Mexico. The exact age of the type specimen from Arroyo Hondo, Camagüey, Cuba, has not been plainly established (Rojas and Iturralde-Vinent, 1996).

Description.-Diameter at the commissure in larger specimens reaches up to $106 \mathrm{~mm}$ anterior-posteriorly and $90 \mathrm{~mm}$ dorsal-ventrally. The RV has an asymmetric low conical 


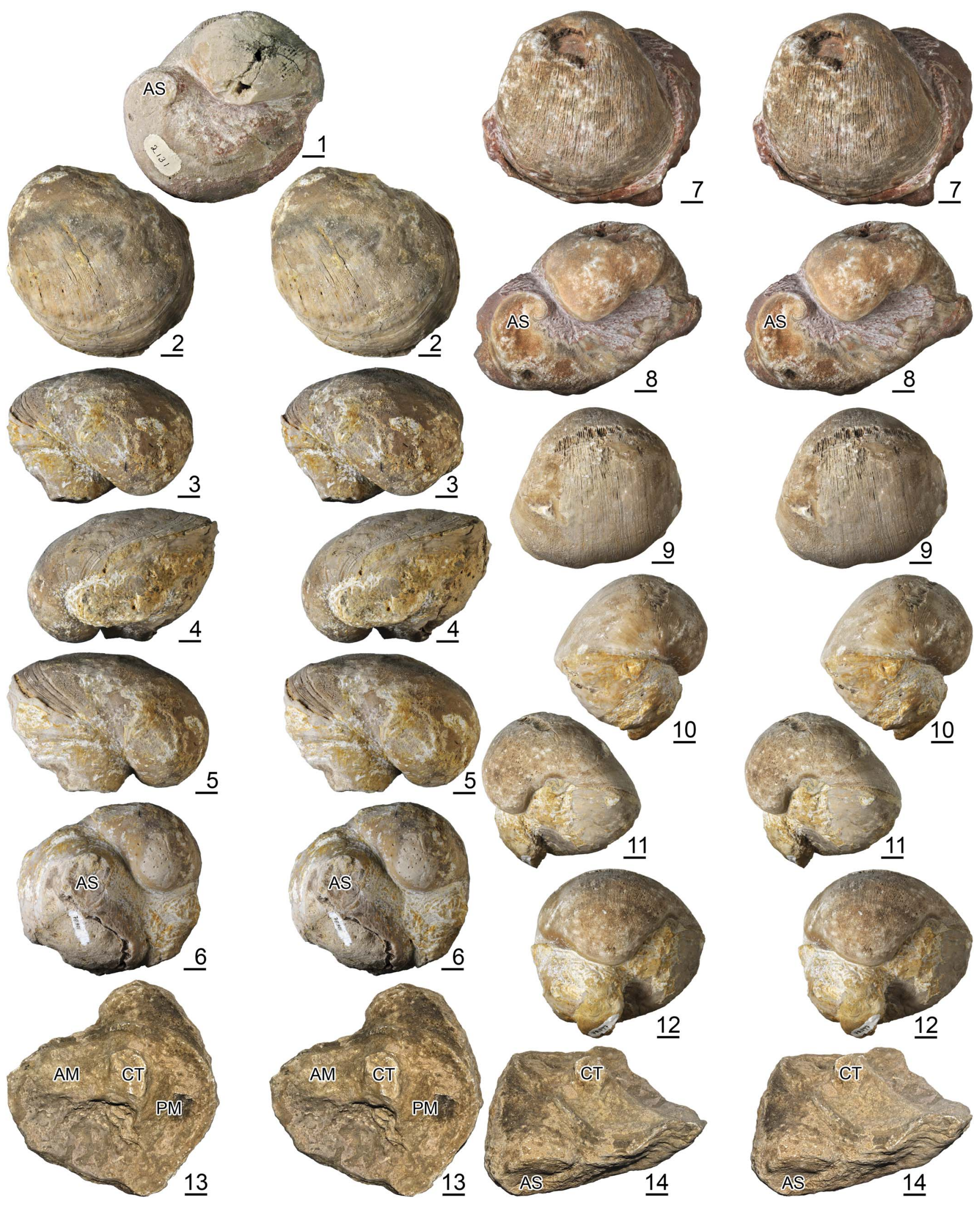

Figure 2. Plagioptychus antillarum (Douvillé, 1927) from road to Paraíso del Grijalva, Suchiapa Formation, middle Campanian, stereo pairs except Figure 2.1; labels indicated in text; scale bars are $10 \mathrm{~mm}$ : (1) IGM-2131, lower view; (2-6) PUAB-78301, upper, dorsal, anterior lateral, posterior lateral, and lower views, respectively; (7, 8) PUAB-78451, upper and lower views, respectively; (9-12) PUAB-78297, upper, anterior, posterior, and dorsal lateral views, respectively; $(\mathbf{1 3}, \mathbf{1 4})$ IGM-10152, RV, anterior-ventral margin broken away, commissural and anterior-dorsal views, respectively. 


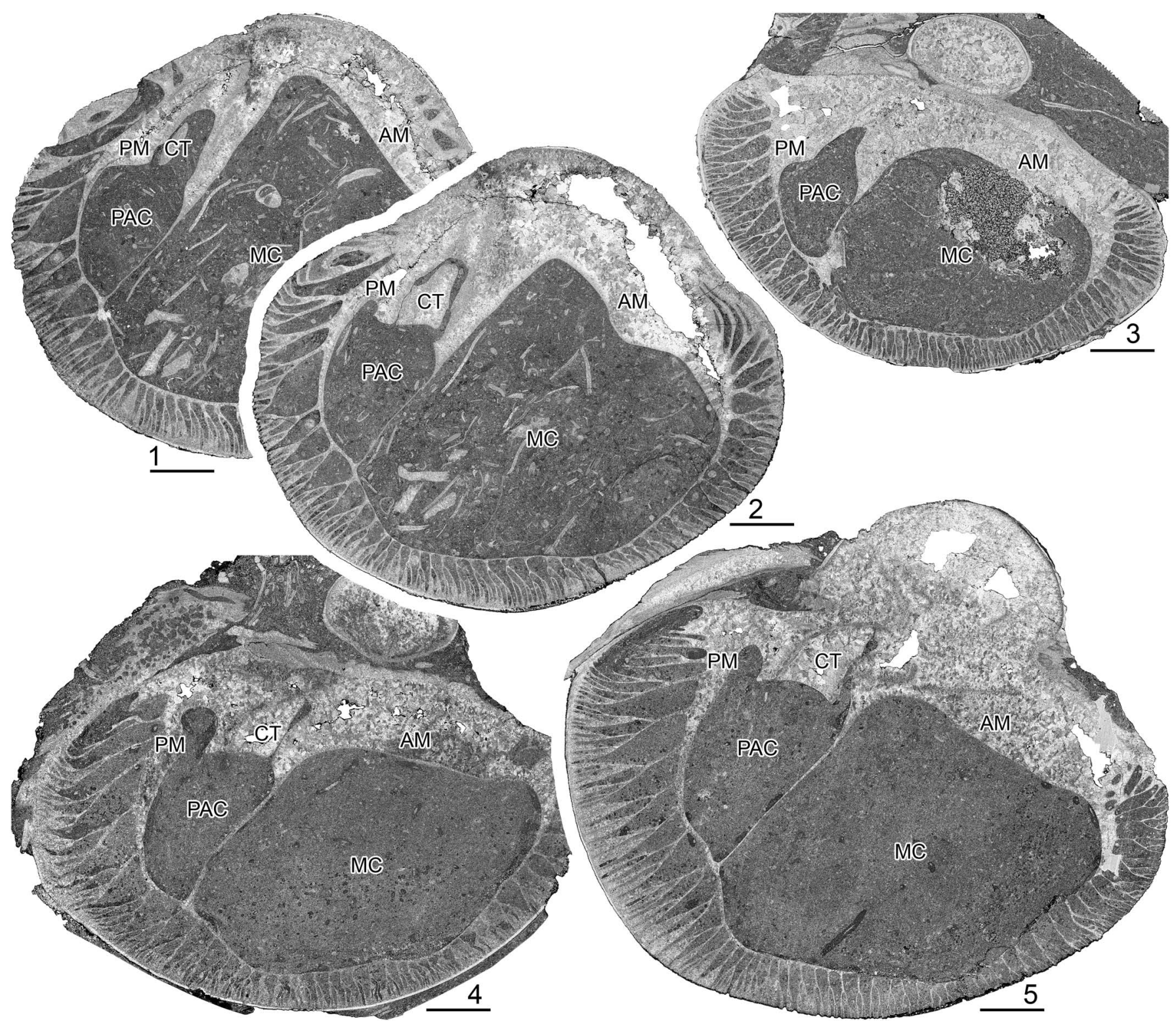

Figure 3. Plagioptychus antillarum (Douvillé, 1927) from road to Paraíso del Grijalva, Suchiapa Formation, middle Campanian, LV's transverse section close to the commissure, acetate peel; labels indicated in text; scale bars are $10 \mathrm{~mm}:(\mathbf{1}, \mathbf{2})$ MPFC-14/02; (3) MPFC-13/113; (4) MPFC-14/41; (5) MPFC-14/39.

form with oblique commissure, produced by coiled growing with a very high expansion rate and vertical component higher ventrally than dorsally. As a result, the umbo is located at the posterior-dorsal margin close to the commissure, forming a flat attachment surface. The outer shell layer, which is rarely preserved, is thick (up to $4 \mathrm{~mm}$ ) and shows prominent growth lines. The LV is low convex above the commissure and has a slightly anteriorly coiled wide umbo considerably projected dorsally, overhanging the commissural plane and covering parts of the RV; thus, linear distances of this valve are larger dorsal-ventrally than anterior-posteriorly, while it is opposite at the commissure. The outer shell layer, which is rarely preserved, is extremely thin $(<1 \mathrm{~mm})$ with fine growth lines; generally, it is weathered and the radial plates of the pallial canals become evident. Umbos of both valves are situated very close to each other.
As seen in transverse cross section of the LV, close to the commissure, the pallial canals of the inner shell layer are quite large at the inner margin. Canal walls are separated up to $3 \mathrm{~mm}$ at the posterior side or $1.5 \mathrm{~mm}$ at the ventral side. The first bifurcation occurs approximately at $1 / 3$ of the inner shell thickness and the second bifurcation at $2 / 3$. Wall bifurcations are relatively symmetrical in most of the valve's circumference, but asymmetrical at the posterior side, where a third bifurcation (or even more) appears ventrally. At the outer margin, 15 walls are counted every $10 \mathrm{~mm}$.

The anterior myophore is very wide and long, but the other myocardinal elements are relatively small, in relation to the size of the valve, and located posteriorly. The base of the anterior tooth is extended in a thin septum delimitating a small posterior cavity. The socket of the central tooth is a long and narrow dorsal extension of this cavity; the tooth, when preserved inside 

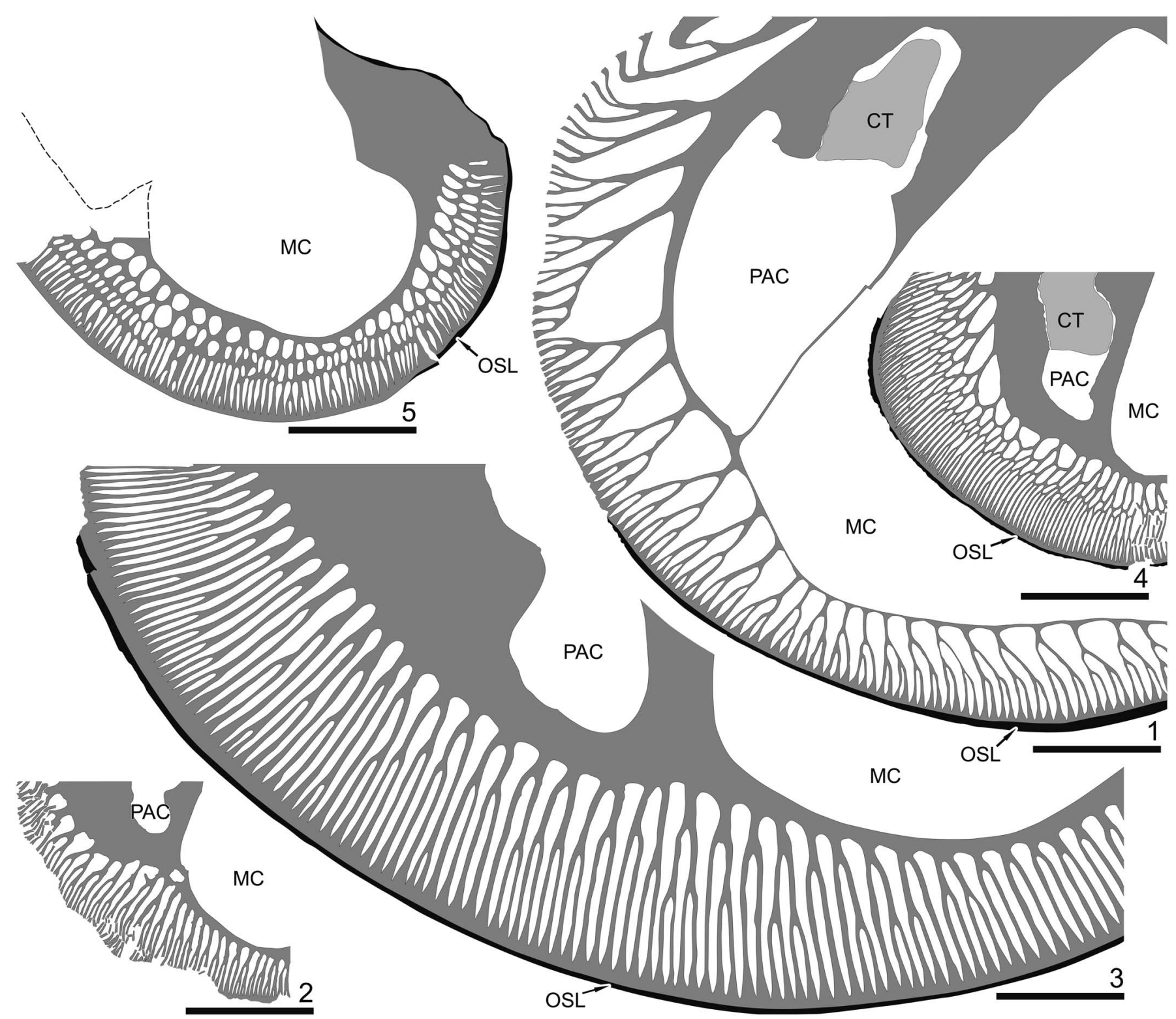

Figure 4. Detail of the LV's pallial canals pattern at the posterior-ventral side, reproduced from acetate peels (except 5, from field picture); labels indicated in text; scale bar is $10 \mathrm{~mm}$ : (1) Plagioptychus antillarum (Douvillé, 1927), FCMP-14/02, road to Paraíso del Grijalva, Suchiapa Formation, middle Campanian, (2) Plagioptychus fragilis Chubb, 1967, PUAB-78367, Rancho La Peregrina, km 198, road Mex145, Angostura Formation, late Maastrichtian. (3) Plagioptychus muellerriedi Alencáster, 1971, PUAB-78335, Campo de Tiro, Ocozocoautla Formation, early Maastrichtian. (4) Mitrocaprina tschoppi (Palmer, 1933), PUAB-81977, Old Quarry, km 195.3, road Mex145, Angostura Formation, late Maastrichtian. (5) Mitrocaprina sp. indet., non-collected, road to Paraíso del Grijalva, Suchiapa Formation, middle Campanian.

the socket, shows a triangular section. The posterior myophore is very thin.

The general form of the shell (Fig. 2.3-2.5), with a RV's umbonal area as attachment surface, an oblique commissural plane, and a LV's umbo considerably projected dorsally, suggests that both valves' umbos probably rested on the substrate. The supposedly heavy LV's umbo, acting as counterbalance, would facilitate the opening of the valves.

Materials.-16 specimens with conjoined valves, P-1316, road to Paraíso del Grijalva, Suchiapa Formation, middle Campanian: PUAB-78297 to PUAB-78302, PUAB-78451, PUAB-78452, FCMP-13/113, FCMP-14/02, FCMP-14/39, FCMP-14/41, FCMP-14/46, FCMP-14/48, FCMP-14/61, and
FCMP-14/67. An isolated RV, IGM-10152. The four specimens of the same locality figured by Alencáster (1971), IGM-2130 to IGM-2133, as well as other specimens from the same locality, all registered with the locality number (\#1999) in the IGM were also examined.

Remarks.-Douvillé (1927) established his species on the basis of a single LV and described and figured its cross section. Douville's specimen is preserved in UCBL-EM and the cross section was reexamined. The two cavities, teeth, myophores, and canals pattern, conform to his description and his figure 2 . All these characters agree in form, position, and relative size with those of our specimens. The supplementary row of large round canals, supporting Douvillés attribution of the species to 
Coralliochama, is interpreted as due to bio-erosion (Entobia) in the compact inner shell layer part at the base of the median septum. The cross section also cuts the umbo located slightly anteriorly (only partially represented in Douvillé's figure), indicating a LV with a wide umbo coiled anteriorly, projecting dorsally, and covering parts of the right valve.

The attribution by Rutten (1936, p. 141-142) of some specimens from the Maastrichtian of northern Santa Clara province, in Cuba, to this species was due to the presence of "rounded irregular cavities" that he interpreted as the supplementary row of large round canals previously described by Douvillé. However, the canals pattern (Rutten's fig. 4c, 4f) is completely different, the cardinal apparatus (Rutten's fig. 4j) is badly preserved, and the form of both valves (Rutten's fig. 4d), with a long, straight, and conical right valve and a small, low, and curved left valve, is by no means similar to that of $P$. antillarum.

Mexican specimens from Müllerried's locality 30 Vega del Paso were referred to Plagioptychus cf. P. jamaicensis (Withfield) by Alencáster (1971), although the pattern of pallial canals was not known in the Jamaican species, because no other large Plagioptychus with a similar form of both valves was known and because a high percentage of rudist species occur simultaneously in both Chiapas and Jamaica. The lectotype of $P$. jamaicensis was found in the Maastrichtian Titanosarcolites Limestone (Guinea Corn Formation in Mitchell, 1999) at Logie Green, Clarendon, Jamaica. This species name should not be used for any other specimen because the internal shell characters of $P$. jamaicensis are unknown.

\section{Plagioptychus fragilis Chubb, 1967 \\ Figures 4.2, 5.1-5.9, 6.1, 6.2}

1967 Plagioptychus fragilis Chubb, p. 27.

1971 Plagioptychus fragilis; Chubb, p. 182, pl. 32, figs. 4, 5. 2016a Plagioptychus sp.; Pons et al., p. 217.

Types.-Originally, UWIGM 1400 and UWIGM 1402b, now NMNH PAL348072 and NMNH PAL245234, respectively, figured in Chubb (1971, pl. 32, figs. 4, 5), from the Shaw Castle Shale of the Titanosarcolites Series of the Maldon Inlier (Shaw Castle Member of the Maldon Formation [formerly Titanosarcolites Series] in Gunter and Mitchell, 2005), St. James, Jamaica, Maastrichtian.

Diagnosis._-"Small; right valve generally low, twisted and exogyrate or perhaps sometimes slipper-shaped; hinge set far back; posterior myophore a small platform supported by a buttress; anterior myophore a thickening of the shell. Left valve only slightly arched, long, delicate, almond-shaped, tending to taper anteriorly; wall thin, its radial plates bifurcate twice or thrice, so the canals near outer margin outnumber those near inner by over four to one; posterior myophore an oblique oval area occupying the cavity behind the septum; anterior myophore a thin deeply undercut shelf" (Chubb, 1967, p. 27).

Occurrence.-Angostura Formation, late Maastrichtian, Chiapas Central Depression, Mexico. The species was previously only known from its type locality in Jamaica.
Description.-Small size shell. Diameter of specimen PUAB-78348 at the commissure $42 \mathrm{~mm}$ anterior-posteriorly and $23 \mathrm{~mm}$ dorsal-ventrally. Its RV has a gyropleuriform flat attachment area of $40 \times 22 \mathrm{~mm}$ and the complete shell reaches $20 \mathrm{~mm}$ height above the attachment surface; the RV's growth, above the ontogenetic early growth phase forming the attachment area, occurs mainly ventrally, the umbo remaining close to the commissure, which is inclined $40^{\circ}$ with respect to the attachment surface; coarse growth lines illustrate this differential ventral growth at the outer shell surface. The LV is almond-shape, has the umbo close to the dorsal margin, is slightly arched with a change in slope near the middle of the valve, and bears conspicuous growth lines at the outer shell surface.

Specimen PUAB-78362 measures in diameter at the commissure $45 \mathrm{~mm}$ anterior-posteriorly and $30 \mathrm{~mm}$ dorsalventrally. Its RV's attachment area measures $42 \times 26 \mathrm{~mm}$ and the complete shell attains $30 \mathrm{~mm}$ above the attachment surface; the commissure is inclined nearly $90^{\circ}$ with respect to the attachment surface. The LV is very slightly arched and the change in slope occurs at $9 \mathrm{~mm}$ of the commissure.

Specimen PUAB-78367 measures in diameter at the commissure $40 \mathrm{~mm}$ anterior-posteriorly and $25 \mathrm{~mm}$ dorsalventrally. Its RV's attachment area measures $38 \times 24 \mathrm{~mm}$ and the complete shell attains $17 \mathrm{~mm}$ above the attachment surface; the commissure is inclined $40^{\circ}$ with respect to the attachment surface. The LV, although very slightly arched, has been sectioned close to the commissure to show the myocardinal elements and the pallial canals structure.

Specimen PUAB-78352 is a free LV, nicely preserved, although broken away at the anterior side, convex because of a change in slope at $9 \mathrm{~mm}$ of the commissure, and with conspicuous growth lines at the outer surface. Diameter at the commissure measures $23 \mathrm{~mm}$ dorsal-ventrally and $22 \mathrm{~mm}$ anterior-posteriorly (the preserved part). The outer shell layer is very thin $(0.2 \mathrm{~mm})$. The inner shell layer with pallial canals is $4 \mathrm{~mm}$ thick at the ventral side close to the median septum, which is its thickest part. The two teeth are situated far back and very close to the valve margin; the anterior tooth is elongated dorsalventrally while the posterior tooth is elongated parallel to the margin and presents a dorsal incision corresponding to the ligament; the anterior myophore is a long narrow platform, anteriorly following the anterior tooth and parallel to the valve margin; the posterior myophore is a wide inwards-inclined platform, separated by a narrow furrow from the posterior tooth and reaching the outer margin of the median septum; the posterior accessory cavity, between the posterior myophore and the median septum, is very small, nearly half of the central tooth's socket. Both teeth and the posterior myophore protrude up to $2 \mathrm{~mm}$ from the commissure while the anterior myophore is $\sim 1 \mathrm{~mm}$ below it. The umbo is aligned with the central tooth's socket.

Specimen PUAB-78361 is a complete free LV, measuring in diameter at the commissure $47 \mathrm{~mm}$ anterior-posteriorly and $28 \mathrm{~mm}$ dorsal-ventrally; although filled with matrix, the tips of both teeth and the posterior myophore are observable; the anterior tooth is situated only $1.5 \mathrm{~mm}$ from the posterior valve margin.

The transverse section of the LV of PUAB-78 shows clearly Plagioptychus-type pallial canals, with walls bifurcating 

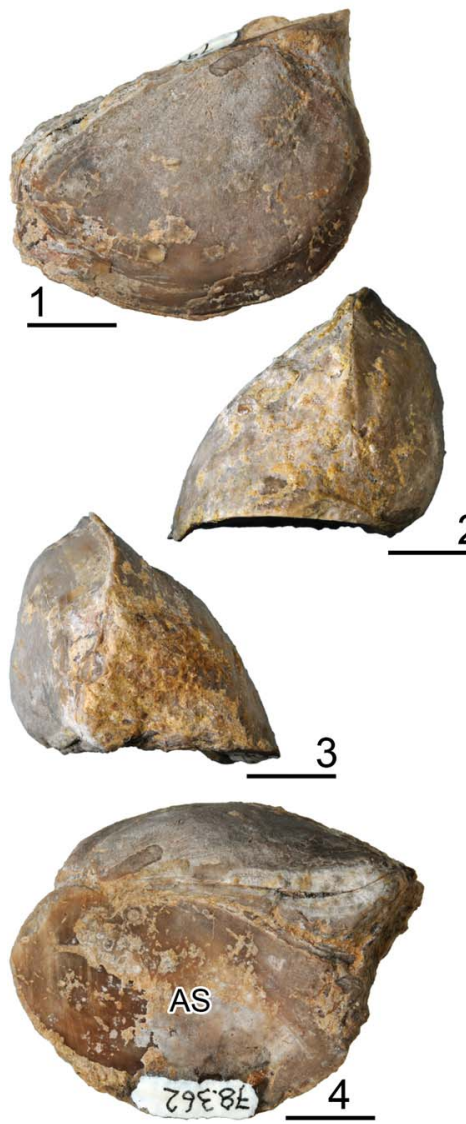
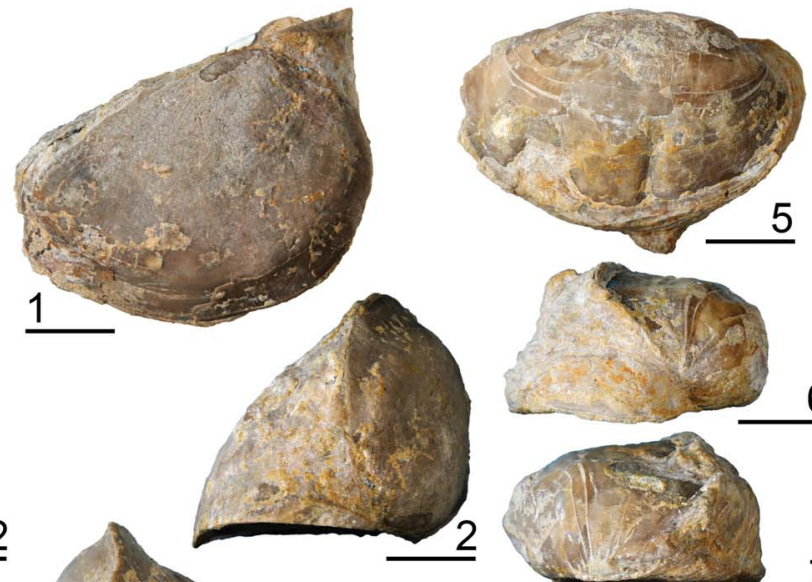

6

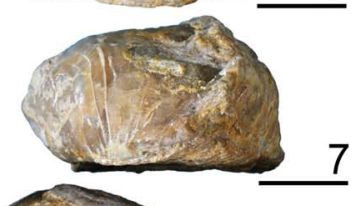

\section{7}
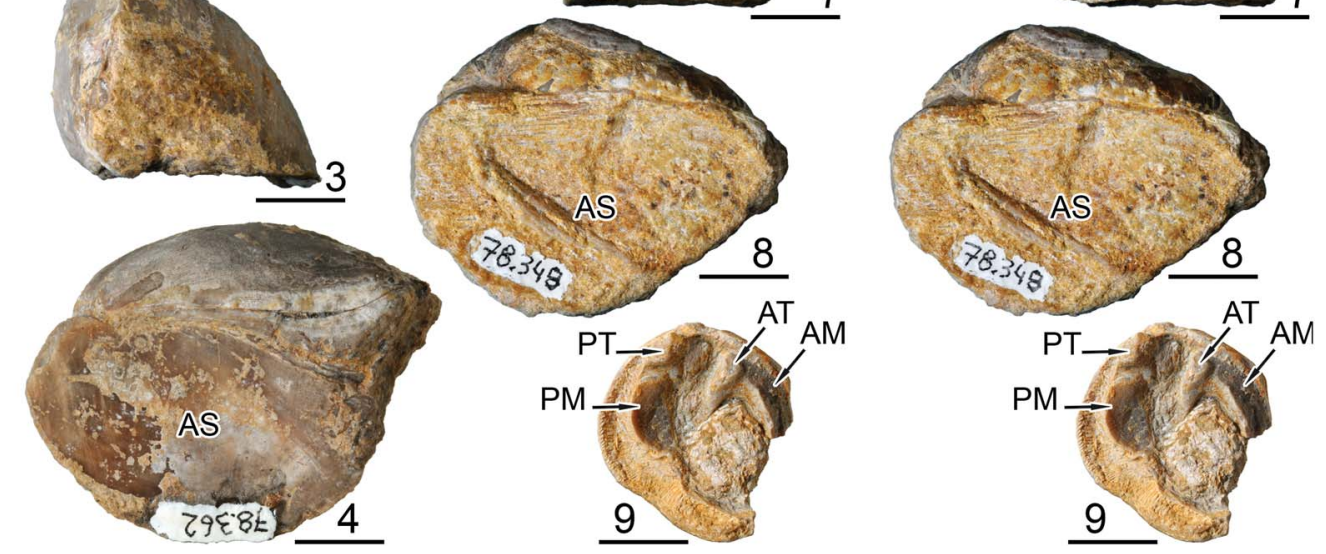

Figure 5. Plagioptychus fragilis Chubb, 1967 from Rancho La Peregrina, km 198, road Mex145, Angostura Formation, late Maastrichtian, stereo pairs; labels indicated in text; scale bars are $10 \mathrm{~mm}$ : (1-4) PUAB-78362, upper, anterior lateral, posterior lateral, and lower views, respectively; (5-8) PUAB-78348, upper, anterior lateral, posterior lateral, and lower views, respectively; (9) PUAB-78352, LV, commissural aspect.

at least once, and up to three times at the ventral-posterior margin. At the inner margin, 12 canals per $10 \mathrm{~mm}$ are counted anteriorly to the median septum and 7 posteriorly; up to 30 at the outer margin.

Materials.-Five specimens from P-0748, Rancho La Peregrina, km 189 road Mex145, Angostura Formation, late Maastrichtian: three with both valves articulated, PUAB78348, PUAB-78362, and PUAB-78367; and two free LVs, PUAB-78352 and PUAB-78361.

Remarks.-The fact that all specimens have an attachment area similar in size to the commissure, clearly suggests an encrusting mode of life.

\section{Plagioptychus muellerriedi Alencáster, 1971}

Figures 4.3, 7.1-7.9, 8.1-8.4

1933 Plagioptychus Arnaudi; Müllerried, p. 4, text-figs. 1-5.

1971 Plagioptychus muellerriedi Alencáster, p. 24, pl. 2, figs. $1-5$, pl. 3 , figs. $1-4$, pl. 17 , fig. 3 .

2005 Plagioptychus muellerriedi; Oviedo, p. 62, textfig. 46.1-46.7.

2016a Plagioptychus muellerriedi; Pons et al., p. 217.
Types.-Holotype: IGM-2134. Paratypes: IGM-2135 to IGM2139, IGM-2141, by original designation, figured in Alencáster (1971, pls. 2, 3, 17), all from Müllerried's locality 6 Ocozocoautla, Ocozocoautla Formation, lower Maastrichtian, Chiapas, Mexico.

Diagnosis.-Medium to large shell, both valves differing in form and size. RV conical, with a flat anterior-dorsal outer surface: limited anteriorly by a keel; developing a wide rounded costa in the middle, enhanced by downwards folding of the growth lamellae; and limited posteriorly by the ligament furrow. LV highly convex, anteriorly coiled umbo overhanging the commissure and fitting with the dorsal rib of the right valve. Pallial canal walls bifurcate twice, the first time very close to the inner margin; canals very narrow and parallel sided. Central tooth, extremely large, fills most of the posterior accessory cavity.

Occurrence.-Upper part of the Ocozocoautla Formation, along the Cuesta NW of Ocozocoautla, lower Maastrichtian, Chiapas Central Depression, Mexico.

Description.-Larger specimens reaching in diameter at the commissure up to $106 \mathrm{~mm}$ anterior-posteriorly and $98 \mathrm{~mm}$ dorsalventrally. The RV is conical, only slightly coiled, and with a small spirogyrate early growth part acting as attachment surface. 


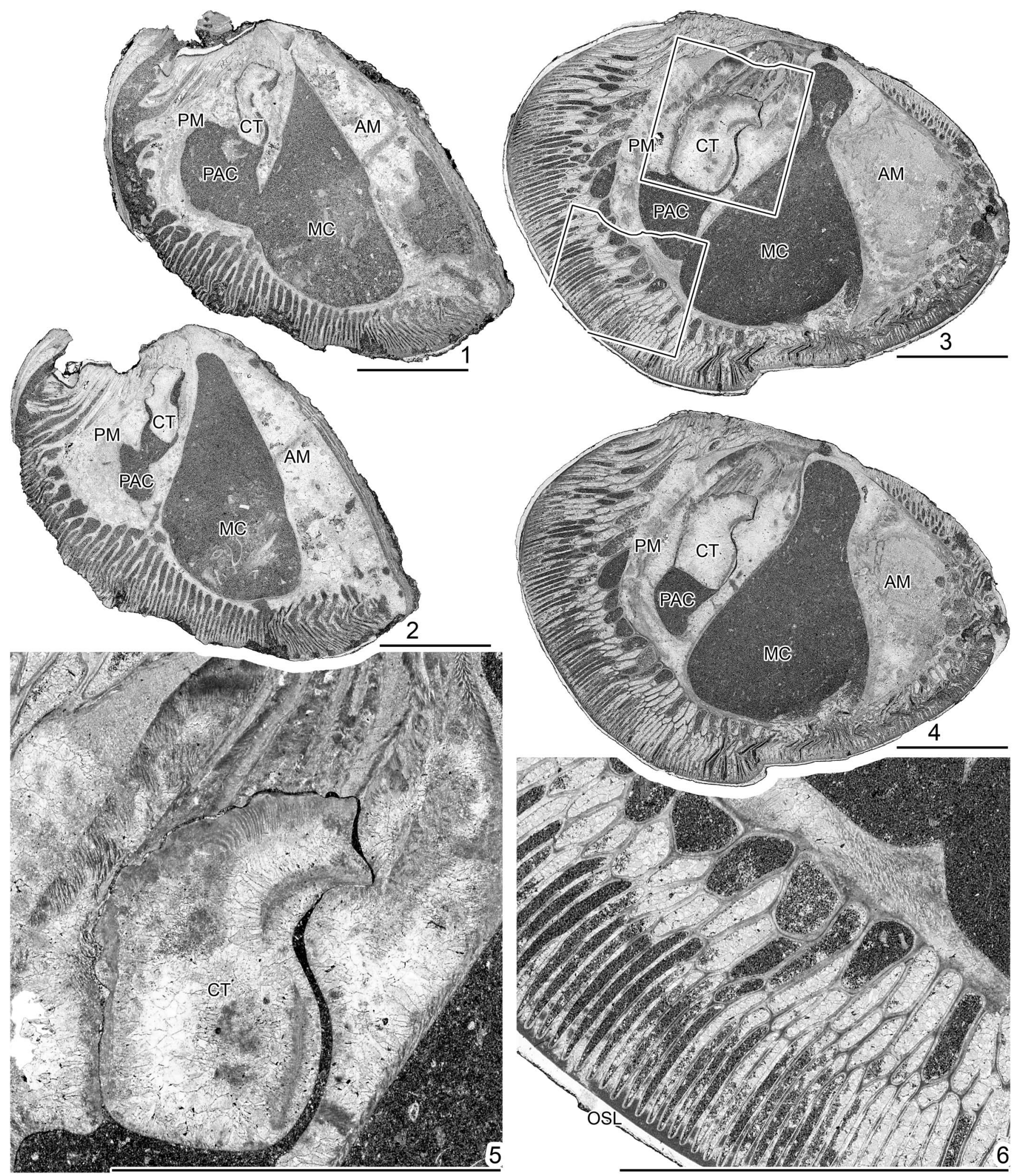

Figure 6. LV's transverse section and details as indicated, acetate peel; labels indicated in text; scale bars are $10 \mathrm{~mm}$ : $(\mathbf{1}, \mathbf{2})$ Plagioptychus fragilis Chubb, 1967, PUAB-78367, from Rancho La Peregrina, km 198, road Mex145, Angostura Formation, late Maastrichtian. (3-6) Mitrocaprina tschoppi (Palmer, 1933), PUAB-81977, from Old Quarry, km 195.3, road Mex145, Angostura Formation, late Maastrichtian.

The anterior-dorsal side is flat, limited anteriorly by a keel and posteriorly by the ligament furrow, and with a wide rounded rib developed in the middle (somewhat anteriorly) enhanced by a down-fold of the growth lamellae. The outer shell layer measures $\sim 2.5 \mathrm{~mm}$ in thickness, and growth lines are evident on all the valve's outer surface. The LV is highly convex, 

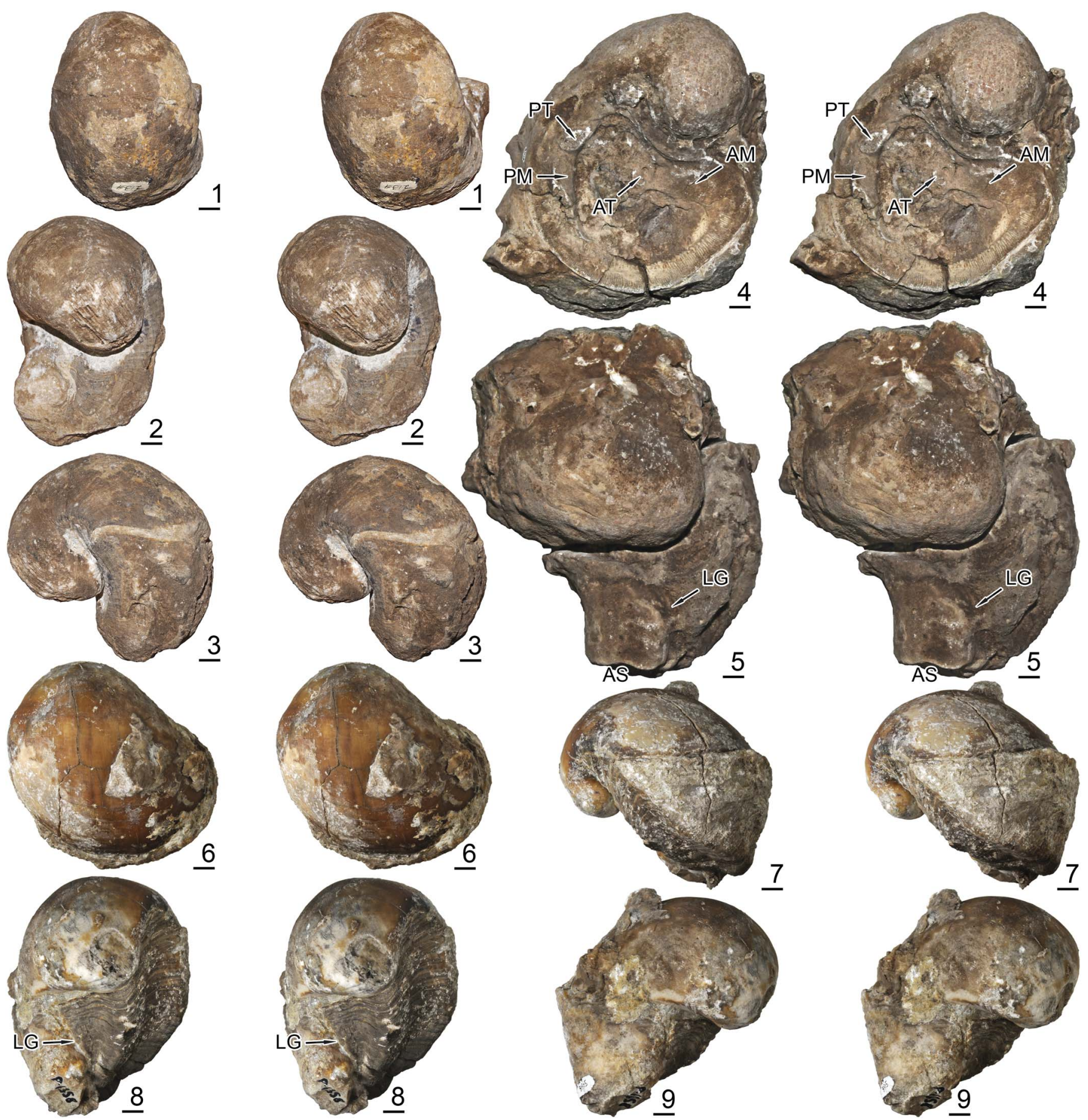

Figure 7. Plagioptychus muellerriedi Alencáster, 1971 from Cuesta NW of Ocozocoautla, Ocozocoautla Formation, early Maastrichtian, stereo pairs; scale bars are $10 \mathrm{~mm}$ : (1-3) IGM-2134, holotype, upper, dorsal lateral, and anterior lateral views of both valves, respectively; $(\mathbf{4}, \mathbf{5})$ IGM-10153, commissural view of LV and dorsal lateral view of both valves, respectively; (6-9) PUAB-81805, upper, anterior, dorsal lateral, and posterior lateral views, respectively.

non-equilateral, with a prominent anteriorly coiled umbo overhanging the commissure and covering parts of the right valve. The outer shell layer is $\sim 1.5 \mathrm{~mm}$ thick and its outer surface is smooth.

As seen in transverse cross section of the LV, close to the commissure, the pallial canals of the inner shell layer are radially long and very narrow $(0.5 \mathrm{~mm}$ close to the inner margin). The first bifurcation of the walls occurs very close to the inner margin; a second bifurcation may occur at any position, only close to the outer margin, or not occur at all; at the area close to the septum limiting the main cavity from the posterior accessory cavity, canals may be wider $(1.5 \mathrm{~mm})$ and more wall bifurcations may develop. At the outer margin, $\sim 20$ walls are counted every $10 \mathrm{~mm}$.

The anterior myophore is very large, with a quadrangular section. The posterior myophore is wide and long, extending 


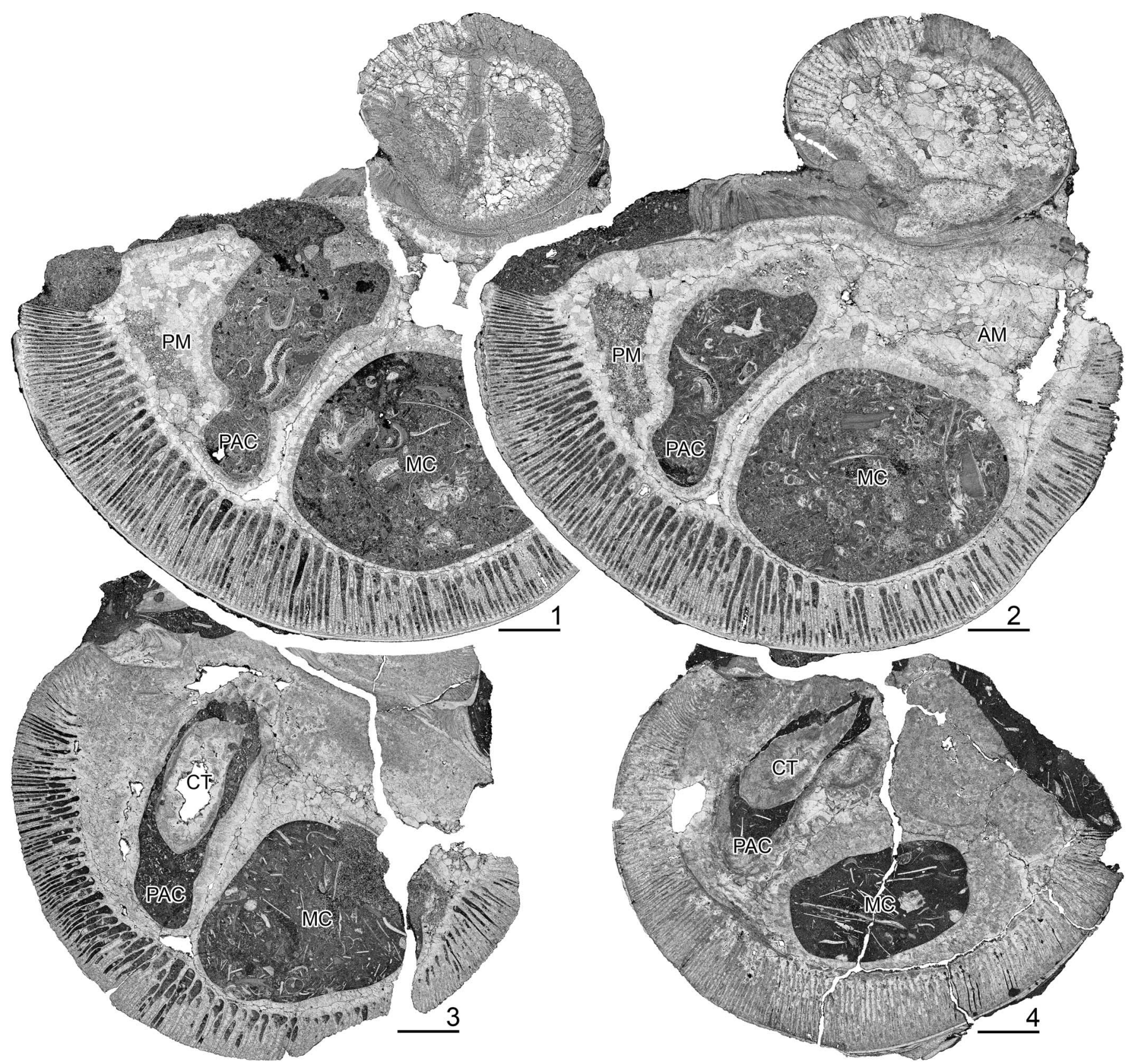

Figure 8. Plagioptychus muellerriedi Alencáster, 1971 from Cuesta NW of Ocozocoautla, Ocozocoautla Formation, early Maastrichtian, LV's transverse section, acetate peel; labels indicated in text; scale bars are $10 \mathrm{~mm}$ : (1-2) PUAB-78335; (3) PUAB-81800; (4) PUAB-81803.

from the margin of the posterior tooth towards the ventral side. The anterior and posterior teeth are relatively small and radially elongated. The base of the anterior tooth is extended in a curved thick septum separating the main cavity, with a rounded section, from the large socket of the central tooth and the small posterior accessory cavity; the RV's central tooth is extremely large and elongated.

Materials.-10 specimens: IGM-10153, PUAB-78242, and PUAB-78335 from P-743 Campo de Tiro, and PUAB-81800 to PUAB-81806 from P-1358 Los Chamaquitos, both Cuesta W of Ocozocoautla, Ocozocoautla Formation, early Maastrichtian, Chiapas Central Depression, Mexico. The holotype (IGM-2134) and paratypes (IGM-2135 to IGM-2141) from the same bed figured by Alencáster (1971) were also examined.

Remarks.-The general aspect of the shell, with a wide rib on the flat surface and the RV umbo pointing anteriorly while that of the $\mathrm{LV}$ points posteriorly, is very characteristic for the anterior-dorsal side of articulated valves. The narrow and parallel-sided pallial canals, as well as the remarkable development of the central tooth, are also distinctive in transverse sections.

\section{Genus Mitrocaprina Boehm, 1895}

Type species.—Coralliochama bayani Douvillé, 1888 from the Hippurites limestone of Rennes-les-Bains, Aude, France. 

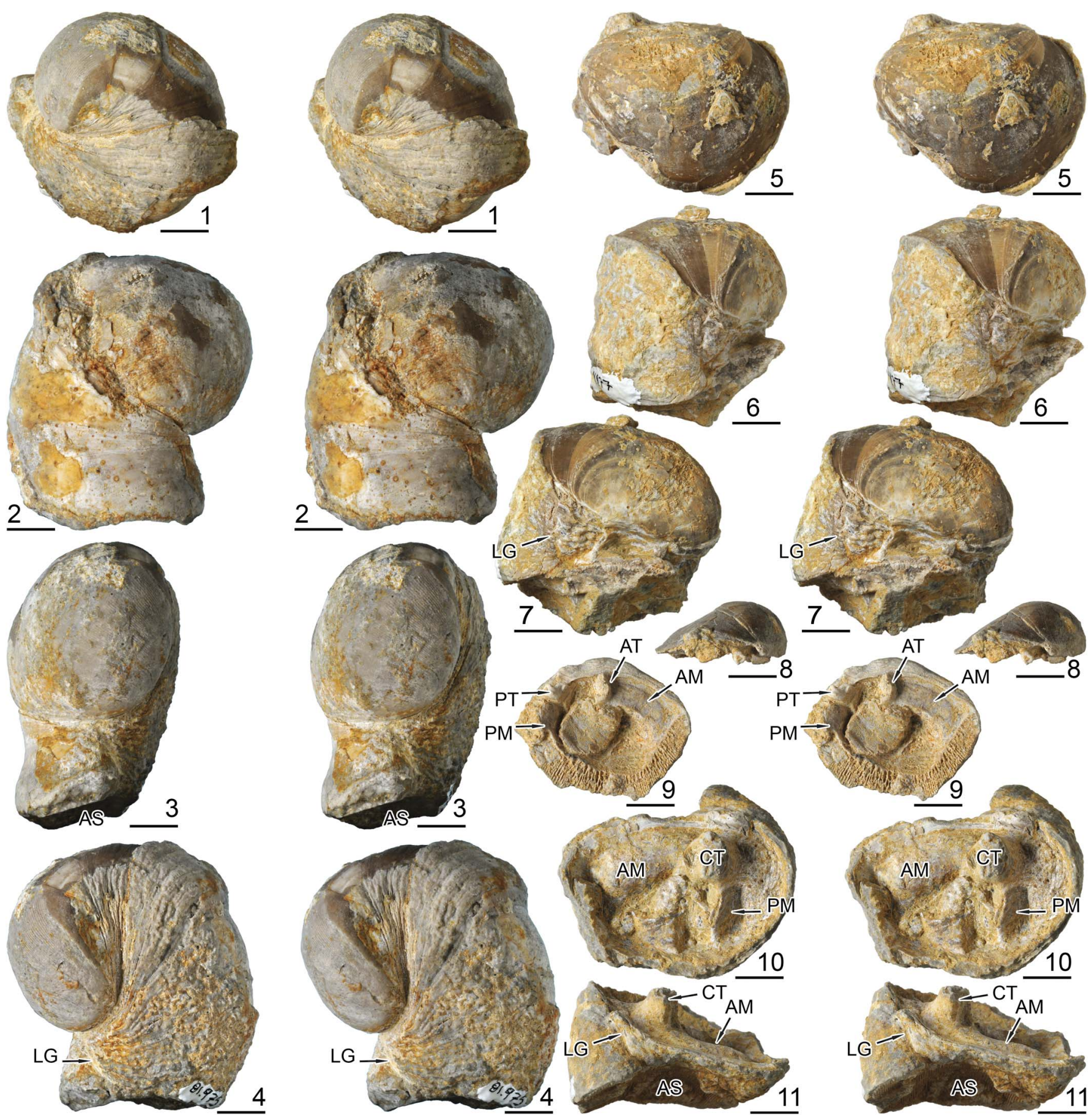

Figure 9. Mitrocaprina tschoppi (Palmer, 1933) from Old Quarry, km 195.3, road Mex145, Angostura Formation, late Maastrichtian, stereo pairs; labels indicated in text; scale bars are $10 \mathrm{~mm}$ : (1-4) PUAB-81975, upper, posterior, dorsal lateral, and anterior lateral views, respectively; (5-7) PUAB-81977, upper, posterior lateral, and dorsal lateral views, respectively; (8, 9) PUAB-81976, LV, dorsal and commissural views, respectively; (10, 11) PUAB-81980, RV, commissural and anterior views, respectively.

Mitrocaprina tschoppi (Palmer, 1933)

Figures 4.4, 6.3-6.6, 9.1-9.11

?1924 Plagioptychus jamaicensis; Trechmann, p. 407, pl. 25, fig. 4 (=Plagioptychus trechmanni, according to Chubb, 1956a).

1933 Plagioptychus tschoppi Palmer, p. 103, pl. 10, figs. 1-3.
1936 Caprinid fragment Thiadens, p. 1011, text-fig. 3.13.

1937 Mitrocaprina tschoppi; MacGillavry, p. 158, pl. 5, fig. 7, pl. 7, figs. $1,4,5,7,8$, pl. 8, figs. 4,7 .

?1956a Plagioptychus trechmanni Chubb, p. 8, text-figs. 1, 2. ?1956b Plagioptychus trechmanni; Chubb, p. 7.

?1971 Plagioptychus trechmanni; Chubb, p. 181, pl. 32, figs. 6, 7 .

non 1975 Plagioptychus tschoppi; Lupu, p. 246 (=?Plagioptychus sp. indet.) 
2004 Mitrocaprina tschoppi; Mitchell and Gunter, p. 393, text-fig. 3, pl. 1, fig. 1, 2.

2005 Mitrocaprina tschoppi; Oviedo, p. 60, text-fig. 44.144.7.

2006 Mitrocaprina cf. tschoppi; Schafhauser, p. 56, pl. 13, figs. 3, 4.

2013 Mitrocaprina tschoppi; Pons et al., p. 751, text-fig. 25. 2016a Mitrocaprina sp.; Pons et al., p. 217.

Holotype.-Palmer (1933, pl. 10, figs. 1-3) figured two complete specimens, 6454 and (?), and a detail of the pallial canals of a third specimen, 6566, all from the same locality \#1032, as indicated in the original labels in the ancient collection at the Unión Nacional de Geología de Cuba. In the present-day repository, new numbers MNHNCu were given with appended annotations concerning old data; one specimen is considered as the holotype, MNHNCu-P.000084 [annotation 6454] and two other, MNHNCu-P.000081 [annotation 5565/1032] and MNHNCu-P.(?), figured specimens. Jimaguayú Formation, Maastrichtian, Ciego de Ávila, Cuba. To our knowledge, there is no publication proposing any lectotype or paralectotypes.

Diagnosis.-Inequivalve. RV with large flat juvenile gyropleuriform attachment area; commissure highly inclined with respect to the attachment surface due to succeeding asymmetric growth; coarse growth lines and a ligament furrow at the outer surface. LV with inconspicuous umbo close to the dorsal margin, smooth and slightly convex early growth phase followed by an abrupt change in slope, producing a highly convex adult valve; up to three rows of radially elongate sub-polygonal canals, not regularly aligned, at the inner part; thin parallel-sided canals, with walls bifurcated or not, at the outer part; at the posterior side, a supplementary fourth row of extremely elongated sub-polygonal canals makes the boundary between both types of canals transitional. Myocardinal elements Plagioptychus-like.

Occurrence.-Angostura Formation, late Maastrichtian, from the Chiapas Central Depression, Mexico. Besides the type locality and Santa Clara (Thiadens, 1936; MacGillavry, 1937) occurrences in Cuba, the species has been reported from the Maastrichtian Guinea Corn Formation in Coffee Piece, Grantham, Jamaica (Mitchell and Gunter, 2004) and the Maastrichtian Cárdenas Formation in Cárdenas, San Luis Potosí, Mexico (Pons et al., 2013).

Description.-Medium size shell. Specimen PUAB-81975, the largest, measures in diameter at the commissure $44 \mathrm{~mm}$ anteriorposteriorly and $35 \mathrm{~mm}$ dorsal-ventrally. Its $\mathrm{RV}$ has a flat (slightly concave) attachment area $35 \times 25 \mathrm{~mm}$ in size, and the complete shell attains $65 \mathrm{~mm}$ above the attachment surface. The RV's growth, above the gyropleuriform attachment area, is not homogeneous. First, heights of $14 \mathrm{~mm}$ at the posterior side and $9 \mathrm{~mm}$ at the anterior are attained, while later, heights of $19 \mathrm{~mm}$ at the posterior side and $63 \mathrm{~mm}$ at the anterior form a commissure extremely inclined ventrally with respect to the attachment surface. Coarse growth lines illustrate this asymmetrical growth at the outer shell surface. The LV, with the umbo close to the dorsal margin and slightly curved anteriorly, is gently arched and smooth at the early growth phase but, when this valve reaches a diameter similar to that attained by the gyropleuriform early growth phase of the right valve, becomes strongly arched after an abrupt change of slope and coarse growth lines become evident at the outer shell surface.

PUAB-81977 is attached by a large area $(43 \times 31 \mathrm{~mm})$ to another shell, diameter at the commissure measures $46 \mathrm{~mm}$ anterior-posteriorly and $37 \mathrm{~mm}$ dorsal-ventrally. The RV is $35 \mathrm{~mm}$ high at the posterior side and $6 \mathrm{~mm}$ at the anterior, and the complete shell reaches $49 \mathrm{~mm}$ above the base; the commissure is deeply inclined anteriorly. The LV is gently arched and smooth; after the early growth phase, the posterior side is more developed than the anterior in correspondence with the asymmetric growth of the RV; it has been sectioned close to the commissure to show the myocardinal elements and the pallial canals structure.

PUAB-81980 is a free RV with large $(42 \times 30 \mathrm{~mm})$ attachment area (on a flabelliform coral); diameter at the commissure measures $50 \mathrm{~mm}$ anterior-posteriorly and $33 \mathrm{~mm}$ dorsal-ventrally; the valve is $30 \mathrm{~mm}$ high at the posterior side and $10 \mathrm{~mm}$ at the anterior, thus, the commissure is slightly inclined anteriorly; the ligament groove is clearly discernible at the outer shell surface and at the commissure; the central tooth emerges $10 \mathrm{~mm}$ above the commissure; the anterior myophore is a large slightly rising platform parallel to the margin and the posterior myophore is an oblique outwards deeply inclined lamina.

PUAB-81976 is a free LV measuring in diameter at the commissure $37 \mathrm{~mm}$ anterior-posteriorly and $28 \mathrm{~mm}$ dorsalventrally; it is gently convex, attaining $13 \mathrm{~mm}$ above the commissure; the two teeth and the posterior myophore protrude $\sim 3 \mathrm{~mm}$ above the commissure while the anterior myophore forms a $1 \mathrm{~mm}$ deep, long rectangular depression below it; the posterior myophore has been broken away, lacking the half close to the median septum; the latter is not observable, being covered by a shell fragment of another specimen; an incision on the dorsal side of the posterior tooth indicates the location of the ligament groove; the umbo is aligned with the boundary between the anterior tooth and the central tooth's socket; the observation of the inner rows of polygonal pallial canals requires a clean surface and high magnification, otherwise it may be overlooked and the canals pattern erroneously interpreted as Plagioptychus-like.

PUAB-81983 is a very small free LV, measuring in diameter at the commissure $14 \mathrm{~mm}$ anterior-posteriorly and $10 \mathrm{~mm}$ dorsal-ventrally; it is partly filled with consolidated sediment obscuring some of the internal details.

The transverse section of the LV of PUAB-81977 shows up to three cycles of sub-polygonal pallial canals, radially elongate and not regularly aligned, at the inner half of the thickness, and thin, radially elongated, parallel-sided canals occupying the outer half; some bifurcations of canal's walls in this last half may be observed; at the posterior side, a fourth row of extremely radially elongated, sub-polygonal canals makes the boundary between both types of pallial canals transitional. The RV's central tooth is preserved inside the socket and has a bean-shape section, concave towards the anterior tooth; the median septum at the ventral side of the base of the anterior tooth delimitates a much-reduced posterior accessory cavity, which is smaller than 
the socket; the section of the posterior tooth and the posterior myophore, extended until the median septum, is wider than the first row of polygonal pallial canals; the section of the anterior myophore is very wide. Ghosts of the original aragonite cross-lamellar microstructure of the inner shell layer may be observed at some points (Fig. 6.5).

Materials.-Five specimens from P-1369, Old Quarry, km 195.3 road Mex145, Angostura Formation, late Maastrichtian, Chiapas Central Depression, Mexico: two with both valves articulated, PUAB-81975 and PUAB-81977; one free RV, PUAB-81980; and two free LVs, PUAB-81976 and PUAB-81983.

Remarks.-The form of both valves, as well as the inclination of the commissure, are highly variable in different specimens, probably because of different orientation of attachment substrates and particular growth needs. Recovered specimens from the type locality in Cuba, as well as those from Jamaica, are larger than the Mexican material from Chiapas and Cárdenas. Chubb (1956a) proposed the new species Plagioptychus trechmanni based on two complete shells with both valves and a free left valve from the Titanosarcolites Series (Guinea Corn Formation in Mitchell, 1999) of Logie Green, Upper Clarendon, Jamaica, which previously were identified by Trechmann (1924) as Plagioptychus jamaicensis (Whitfield). The external characters of both valves are coincident with those in Mitrocaprina tschoppi and the LV's state of preservation does not allow a precise characterization of the pallial canals' pattern, thus, reasonable doubts arise on the attribution of the species name trechmanni to Plagiopthychus and we consider it could correspond to a Mitrocaprina, thus becoming a junior synonym of M. tschoppi. The size is similar to that of the Mexican material described herein.

\section{Mitrocaprina species indeterminate} Figure 4.5

Remarks.-In the uppermost part of the Suchiapa Formation, middle Campanian, at the road to Paraíso del Grijalva, some weathered sections, intercalated in hard bioclastic limestones, have been observed and photographed, but could not be sampled. One of the most complete among these specimens, interpreted as the transverse section of a plagioptychid $\mathrm{LV}, \sim 40 \mathrm{~mm}$ anteriorposteriorly and $30 \mathrm{~mm}$ dorsal-ventrally, shows a regularly aligned arrangement of pallial canals at the inner shell layer: an internal row of sub-rounded pallial canals, $1.3 \times 1.8 \mathrm{~mm}$ in diameter; a second row of radially elongated sub-rounded canals, $0.7 \times 1.3 \mathrm{~mm}$, approximately doubling in number those of the first row; at what seems the area close to the median septum, a third row of smaller radially elongated sub-rounded canals develops; the outer part presents one row of very thin, $0.3 \mathrm{~mm}$ wide, parallel-sided, radially oriented canals, approximately as long as the addition of the two internal rows. The outer shell layer is very thin.

There is no doubt in attributing these specimens to Mitrocaprina, but the specific determination remains uncertain. The pattern of the pallial canals, as far as it can be observed without the acetate peel of a polished section, is similar to that in the Maastrichtian species M. tschoppi in the development of the outer row of thin parallel-sided, radially oriented canals, but differs mostly in its inner part: canals sub-rounded, aligned in regular rows, and in two rows, instead of sub-polygonal, not regularly aligned, and in up to three rows; the occurrence of more canals in the area close to the median septum is coincident in both. There is no information about the form of the shell other than the incomplete transverse section of the left valve.

\section{Discussion}

Genus Plagioptychus.-The three Plagioptychus species described above from Chiapas show evident differences between each other with regard to size, growing form of each valve, and pattern of both the myocardinal elements and the LV's pallial canals. They are each of different age (middle Campanian, early Maastrichtian, and late Maastrichtian) and, apparently, not very closely related phylogenetically, but belong to different specific evolutionary lineages. The characters of most other American Plagioptychus species are insufficiently known, which prevents any thorough phylogenetic analysis. Diversity in most characters among Mediterranean Plagioptychus species is similar to that of American ones.

Genus Mitrocaprina.-The Mitrocaprina from Chiapas described above have in common a character never previously described in any Mediterranean Tethys Mitrocaprina: a wide outer row of thin parallel-sided, radially oriented canals, occupying half the width of the LV's inner shell layer. In Mediterranean species, polygonal or sub-polygonal canals occupy almost all the width. It can be hypothesized that the Campanian undetermined species described above and the Maastrichtian M. tschoppi are, in view of their similarities, two members of a single phylogenetic lineage, but it can be also speculated that the differences between Mediterranean and American plagioptychids go beyond the species level.

Genus Coralliochama.-Although reported in the Caribbean, most records of Coralliochama actually refer to different genera. Müllerried (1931a) made Coralliochama radiolitiformis Trechmann, 1924, the type species of the radiolitid genus Chiapasella. Coralliochama antillarum Douvillé, 1927, from Arroyo Hondo, Cuba, is recognized as a valid species of Plagioptychus.

Alencáster (1971) proposed the new species Plagioptychus agariciformis, based on three specimens indicated as coming from Müllerried's locality 6, Ocozocoautla. Subsequent research on the type specimen (García-Barrera et al., 1998) showed it really corresponds to Coralliochama gboehmi Böse, 1906, which is a common species in the Cárdenas Formation at Cárdenas. Intensive research and collecting through the Ocozocoautla's rudist bed, for more than twenty years, did not provide a single specimen of this species, while another plagioptychid, P. muellerriedi, occurs abundantly there. The preservation of Alencáster's type is excellent and extremely similar to that of Cárdenas' specimens, but very different from what is common in Ocozocoautla. Böse's (1906) collection of Cárdenas fossils is preserved at the IGM, as is Müllerried's collection on which Alencáster's (1971) work was based. We consider the possibility that some cross-mixing of labels was 
possible; before being definitively deposited at the IGM, Mexican fossil collections were transferred from the ancient Museum. In our opinion, up to now, the record of genus Coralliochama in Chiapas is doubtful. The genus is recorded from northern and central Mexico, but not from the Caribbean.

Other genera.-Recent taxonomic papers on American Late Cretaceous rudist faunas (Pons et al., 2010, 2013, 2016b), besides the proposal of new plagioptychid taxa, reported other taxa in open nomenclature owing to the lack of diagnostic characters. Nevertheless, some of the characters illustrated by these indeterminate taxa suggest they cannot be ascribed to any of the known genera. This indicates that diversity among American Plagioptychidae may be wider than recognized today, resulting in a more significant difference to those of the Mediterranean Tethys than previously assumed.

\section{Acknowledgments}

Fieldwork in Chiapas was financed by the Spanish Ministerio de Economía y Competitividad, project CGL2011-25581. The Facultad de Ciencias of the UNAM, the Coordinación Técnica de Investigación of the SEMAHN, and the Museo de Paleontología 'Eliseo Palacios Aguilera' provided logistic support. M.J. Avendaño-Gil, I.E. Nieto, and A. Oviedo, shared with us several field journeys. J. Alvarado and V. Romero allowed us working on the Colección Nacional de Paleontología in their care. I.E. Nieto and L. Martín assisted with the preparation of specimens in the laboratory of the Museo de Paleontología of the Facultad de Ciencias of the UNAM. A. Prieur and E. Robert allowed us to work on the Collection de l'École nationale supériéure des Mines de Paris in their care. J. Gallemí helped with the first English version of the manuscript. Concerns and suggestions of S. Mitchell, another anonymous reviewer, the Associated Editor M. Hautmann, and the Editor-in-Chief J. Jin, helped improve the manuscript. All these persons and institutions are gratefully acknowledged.

\section{References}

Alencáster, G., 1971, Rudistas del Cretácico Superior de Chiapas. Parte 1: Paleontología Mexicana, n. 34, p. 1-91.

Alencáster, G., and Michaud, F., 1991, Rudistas (Bivalvia-Hippuritacea) del Cretácico superior de la región de Tuxtla Gutiérrez, Chiapas (México): Actas Facultad de Ciencias de la Tierra UANL, n. 4, p. 175-193.

Alencáster, G., and Pons, J.M., 1992, New observations on the Upper Cretaceous rudists of Chiapas: comparison between American and European faunas and taxonomic implications: Geologica Romana, v. 28, p. 327-339.

Boehm, G., 1895, Beiträge zur Kenntniss der Kreide in den Südalpen. 1 Die Schiosi- und Calloneghe-Fauna: Palaeontographica, v. 41, p. 81-148.

Böse, E., 1906, La fauna de moluscos del Senoniano de Cárdenas, S.L.P.: Boletín del Instituto de Geología de México, n. 24, p. 1-92.

Chubb, L.J., 1956a, Some rarer rudists from Jamaica, B. W. I.: Palaeontographica Americana, v. 4, n. 26, p. 1-30.

Chubb, L.J., 1956b, Rudist assemblages of the Antillean Upper Cretaceous (Cuba and Jamaica): Bulletin of American Paleontology, v. 37, n. 161, 23 p.

Chubb, L.J., 1967, New rudists species from the Cretaceous rocks of Jamaica: The Journal of the Geological Society of Jamaica, v. 9, p. 24-31.

Chubb, L.J., 1971, Rudists of Jamaica: Paleontographica Americana. v. 7, n. 45, p. $161-257$.

Douvillé, H., 1888, Études sur les Caprines: Bulletin de la Société Géologique de France (3), v. 16, p. 699-730.

Douvillé, H., 1927, Nouveau rudistes du Crétacé de Cuba: Bulletin de la Société Géologique de France (4), v. 27, p. 49-56.
García-Barrera, P., Avendaño Gil, J., Omaña, L., and Alencáster, G., 1998 Antillocaprina trilobata nov. sp. and Upper Cretaceous associated fauna from Chiapas, southeast Mexico, in Masse, J.-P., and Skelton, P.W., eds., Quatrième Congrès international sur les Rudistes: Geobios, Mémoire spécial, n, 22, p. 126-135.

Gunter, G.C., and Mitchell, S.F., 2005, The lithostratigraphy of the Maldon Inlier, northwestern Jamaica: Caribbean Journal of Earth Science, v. 38, p. 1-10.

Lupu, D., 1975, Faune Sénonienne à rudistes de la province de Pinar del Río (Cuba): Dări de seamă ale şedintelor. 3: Paleontologie, v. 61 (1973-1974) p. 223-254.

MacGillavry, H.J., 1937, Geology of the Province of Camaguey, Cuba, with revisional studies in rudist Paleontology [Ph. D. dissertation]: Utrecht, University of Utrecht, $168 \mathrm{p}$.

Matheron, P., 1842, Catalogue méthodique et descriptif des Corps organisés fossiles du département des Bouches-du-Rhône et lieux circunvoisins; précedé d'un Mémoire sur les terrains supérieurs au grès bigarré du S.E. de la France: Répertoire des travaux de la Société de Statistique de Marseille, v. 6, p. 81-341.

Mitchell, S.F., 1999, Stratigraphy of the Guinea Corn Formation (Upper Cretaceous) at its type locality between Guinea Corn and Grantham (northern Clarendon): Journal of the Geological Society of Jamaica, v. 33, p. 1-12.

Mitchell, S.F., 2013, Revision of the Antillocaprinidae Mac Gillavry (Hippuritida, Bivalvia) and their position within the Caprinoidea d'Orbigny: Geobios, v. 46, p. 423-446.

Mitchell, S.F., and Gunter, G.C., 2004, First record of the rudist bivalve Mitrocaprina tschoppi (Palmer) from the Maastrichtian of Jamaica: Caribbean Journal of Science, v. 40, p. 392-396.

Müllerried, F.K., 1931a, Chiapasella, un paquiodonto extrañísimo de la América: Anales del Instituto de Biología UNAM, v. 2, p. 243-254.

Müllerried, F.K., 1931b, Sobre una anomalía en las invaginaciones de las valvas de algunas Hippuritidae: Anales del Instituto de Biología UNAM, v. 2, p. $255-261$.

Müllerried, F.K., 1933, El género Plagioptychus en México: Anales del Instituto de Biología UNAM, v. 4, n. 1, p. 1-14.

Müllerried, F.K., 1934, Sobre el hallazgo de paquiodontos gigantescos en el Cretácico de Chiapas: Anales del Instituto de Biología UNAM, v. 5, p. $81-82$.

Müllerried, F.K., 1936, La edad estratigráfica de la Barrettia y formas cercanas: Anales del Instituto de Biología UNAM, v. 7, p. 155-164.

d'Orbigny, A., 1840, Note sur le genre Caprine: Revue Zoologique de la Société Cuvierienne, v. 1839 , p. 168-170.

Oviedo, A., 2005, Rudistas del Cretácico superior del centro al sureste de México (recuento sistemático de rudistas americanos) [Ph. D. Dissertation]: Bellaterra, Universitat Autònoma de Barcelona, 113 p. <http://www.tdx. cat/TDX-0620106-232433 > [accessed December 2016].

Palmer, R.H., 1933, Nuevos Rudistas de Cuba: Revista de Agricultura, Comercio y Trabajo, v. 14, n. 15-16, p. 92-125.

Pons, J.M., Vicens, E., Pichardo, Y., Aguilar, J., Oviedo, A., Alencáster, G., and García-Barrera, P., 2010, A new early Campanian rudist fauna from San Luis Potosí in Mexico and its taxonomic and stratigraphic significance: Journal of Paleontology, v. 84, p. 974-995.

Pons, J.M., Vicens, E., Oviedo, A., Aguilar, J., García-Barrera, P., and Alencáster, G., 2013, The rudist fauna of the Cárdenas Formation, Maastrichtian, San Luis Potosí State, Mexico: Journal of Paleontology, v. 87, p. 726-754.

Pons, J.M., Vicens, E., Martínez, R., García-Barrera, P., Nieto, I.E., Oviedo, A., and Avendaño-Gil, M.J., 2016a, The Campanian-Maastrichtian rudist bivalves succession in the Chiapas Central Depression, Mexico: Cretaceous Research, v. 60, p. 210-220.

Pons, J.M., Vicens, E., and Schmidt-Effing, R., 2016b, Campanian rudist (Hippuritida, Bivalvia) from Costa Rica (Central America): Journal of Paleontology, v. 90, p. 211-238.

Rojas, R., and Iturralde-Vinent, M., 1996, Checklist of Cuban rudist taxa: Revista Mexicana de Ciencias Geológicas, v. 12 (1995) p. 292-293.

Rutten, M.G., 1936, Rudistids from the Cretaceous of northern Santa Clara province, Cuba: Journal of Paleontology, v. 10, p. 134-142.

Schafhauser, A., 2006, The Cárdenas Formation in East-Central Mexico (Maastrichtian): stratigraphy, depositional environment and rudist decline. [Ph. D. Dissertation]: Karlsruhe, Karlsruhe University, 106 p. $<$ http://digbib.ubka.uni-karlsruhe.de/volltexte/1000004246> [accessed December 2016].

Thiadens, A.A., 1936, Rudistids from southern Santa Clara, Cuba: Koninklijke Akademie van Wetenschappen te Amsterdam, Proceedings, v. 39, n. 8 , p. $1010-1019$.

Trechmann, C.T., 1924, The Cretaceous Limestones of Jamaica and their Mollusca: Geological Magazine, v. 61, p. 385-410.

Accepted 31 October 2016 